\title{
Historein
}

Vol 14, No 1 (2014)

On the Edge of History and Philosophy

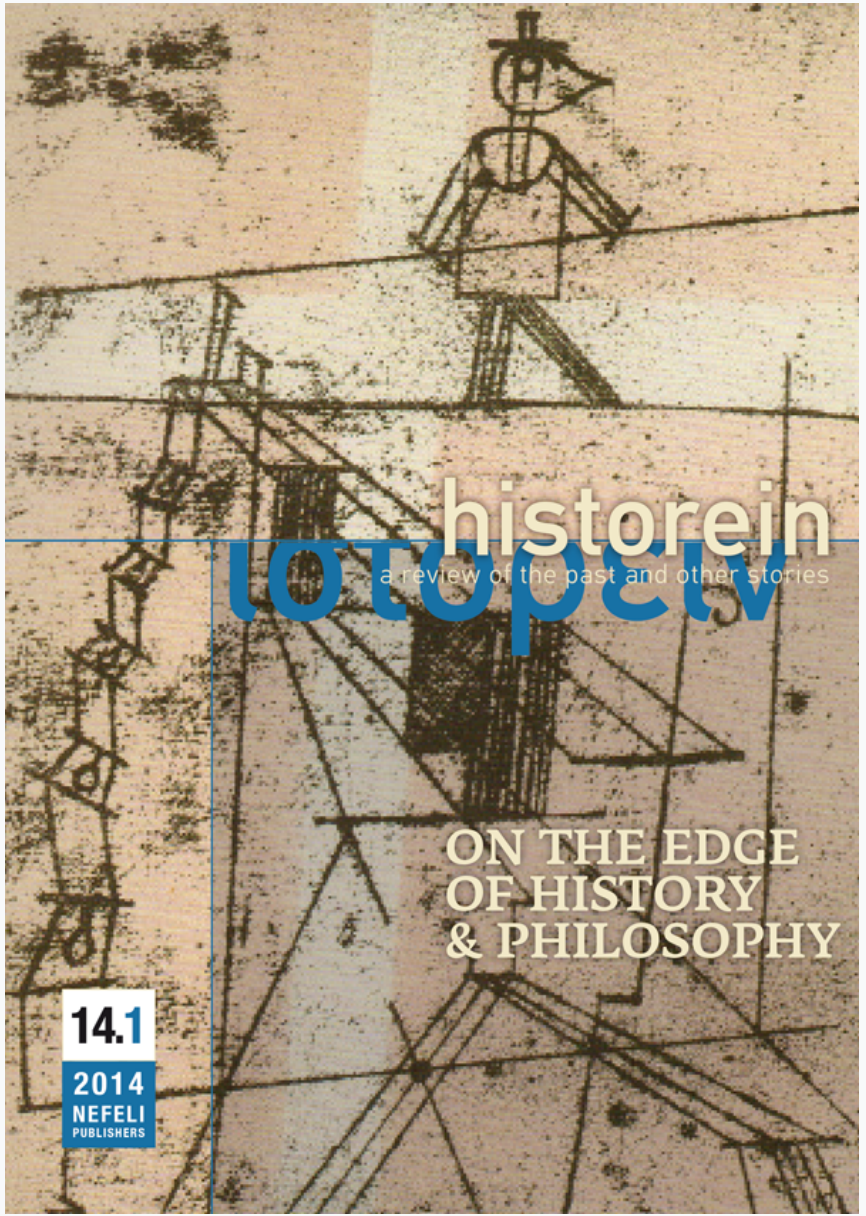

\section{Review of D. Stone (ed.), The Holocaust and Historical Methodology}

Haris Exertzoglou

doi: $10.12681 /$ historein.225

Copyright @ 2014, Haris Exertzoglou

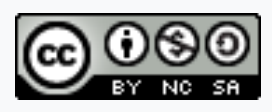

This work is licensed under a Creative Commons Attribution-NonCommercialShareAlike 4.0.

\section{To cite this article:}

Exertzoglou, H. (2013). Review of D. Stone (ed.), The Holocaust and Historical Methodology. Historein, 14(1), 112-119. https://doi.org/10.12681/historein.225 


\section{Dan Stone (ed.)}

\section{The Holocaust and Historical Methodology}

\section{New York: Berghahn, 2012. 323 pp.}

\section{Haris Exertzoglou}

University of the Aegean

Another book about the Holocaust? This question comes immediately to mind when a new book on the Holocaust is published because it has topped the list of the most researched and debated issues for two decades. It is obvious today, perhaps more obvious than it was years ago, that the Holocaust is not a unified event, that the term Holocaust historiography stands for all attempts to explain this horrific event, by examining all initiatives at local and higher level that brought about the destruction of European Jewry and, to a lesser degree, to integrate the individual experiences of European Jews of terror, death and suffering, as well as the cases of resistance and defiance, into a common narrative. However, the historiography of the Holocaust is uneven because most works are mainly interested in explaining the Holocaust in terms of "why" and "who", putting emphasis mostly, if not exclusively, on official documents from the side of the perpetrators. Most historians avoid making major philosophical, aesthetic of even interpretive assessments about their findings, as they struggle to find more and more hard evidence and put it in some kind of narrative order. However, unearthing new documentary material does not necessarily assure interpretive consensus about the Holocaust or putting it to rest as a past that was once but is no more. The Holocaust is not something that has passed; on the contrary, it is very much part of our present because western societies recognise in it, and with good reason, the failure of western civilisation to defend moral and ethical issues deemed universal and valuable. I do not suggest that the Holocaust is the only event in history used by subsequent societies for their own present purposes - in fact, every past event can serve present needs - but the extermination of European Jewry is considered the most emblematic example of the failure of European modernity. Cohorts of scholars from different quarters gave themselves the task of documenting and interpreting these events in various contexts. After the collapse of the Eastern bloc, new material regarding the Holocaust came to light due to the opening to research of the archives in the former socialist countries. In addition, the voice of survivors who fought with their own individual trauma and decided to talk about their suffering, usually many years after the event, added a new dimension into the study of the Holocaust. Last but not least, the Holocaust proved fertile ground for artistic representations in literature, film and television series. Needless to say, the study of the Holocaust has incited fierce debates about historical perspectives, methodologies and modes of representation among historians and social scientists, all of which seem to belie the simplistic view that the Holocaust is the argument of last resort put forward by those who take its factuality as evidence of its interpretive fixity and closure. Interest in the Holocaust was not limited to scholarly or artistic grounds alone but also involved strong political connotations. In fact, the Holocaust was and still is a deeply political and moral issue, as the connection between the extermination of European Jewry with the founding myth of the state of Israel attests. In the Arab countries and the Islamic world, the view prevails that the Holocaust was simply the excuse for the colonisation of Palestine and the eviction of its Arab population and that, therefore, the sacralisation of the Holocaust was simply one of the means 
used to legitimise the usurpation of Arab land. Thus, under this light, many openly deny that the extermination of the Jews ever took place. A similar issue is raised in various quarters in the west by people on the right and the left who deny the Holocaust from different angles and in relation to different political agendas. Initially being a distasteful but marginal phenomenon in the west, Holocaust denial has gained some ground in recent years and it will probably gain momentum with the rise of the extreme right and fascism in European societies today. In other words, the Holocaust was not and probably will never be simply a conventional historical issue, if we believe that there are such issues, but a hotly debated field from different perspectives and political positions. This implies that the meaning of the Holocaust will remain questionable and its representation problematic, despite the available documentary material.

The Holocaust and Historical Methodology is, in my mind, a very interesting and timely contribution to the study of the Holocaust by a younger generation of historians. Edited by historian Dan Stone, it is a collection of essays focusing on different aspects of the study of the Holocaust. Issues are raised not only in relation to the historiography of the Holocaust but also on the methodologies used by historians to grasp the series of events lumped together under the term Holocaust. The book is divided into four parts. The first focuses on memory and culture in the Third Reich, with contributions from Alon Confino, Dan Stone, Dirk Rupnow, Amos Goldberg and Boaz Neuman. Confino discusses racial ideology, the radicalisation of Nazi policy and the context of the second world war as three key categories of interpretation used in the study of the Holocaust, and he proposes new directions which might reveal previously unobserved aspects of this past. Noting that a combination of ideology, ra- cialisation and the war context have constituted the dominant interpretive framework in the study of the Holocaust and that most historians working in this field have followed some variation of this combination, Confino proceeds with questioning these categories, exposing their insufficiency in dealing with the central question of why the Nazis raised the battle against the "Jew", which, for all reasons, was without any practical purpose or, as some would say, "irrational". The author suggests that Auschwitz was made possible because "planning a world without Jews" was a vision embedded in the mental and cultural universe of the Germans, coexisting of course with other opposite visions. If this is true, if the project of exterminating the "Jew" extended beyond the Nazi period, then historians should consider the continuities between this period and previous phases of German history in order to understand the fantasies and memories which mobilised modern German antisemitism. Stone's informative essay complements his introduction to this volume about the historiography of the Holocaust, the methodological issues involved as well as the uses of the Holocaust in the postwar era. He insists that the meaning of the Holocaust is not self-evident but is forged by historical writing, thus involving not only different approaches but also different modes of narrativisation. The Holocaust was declared as a unique event and all attempts to historicise it failed due to the moral burden of the extermination of European Jewry in postwar Europe. As a unique event, the Holocaust eclipsed all other limit events and no other atrocity could reach its sublime status. By limit event I mean an event of such magnitude and profound violence that its effects rupture the otherwise normative foundations of legitimacy that underlie the constitution of political and moral community. The Holocaust is the case in point par excellence. Stone calls for new interpretive perspectives which will move the study of the 
Holocaust to new ground, believing that cultural history could provide this momentum. He addresses the paradox that cultural history, successful though it is in many other fields of historical studies, has failed to influence the study of the Holocaust, at least to a considerable degree, which remains largely traditional in scope. Existing studies on the Holocaust drew on the kind of material, mostly Nazi documents and official ideology, that underestimates the fantasies, imagination and hallucinations which also informed Nazi politics and can better explain the genocidal turn of the Nazis. To that end, Stone believes the use of cultural history perspectives could be very useful. Goldberg criticises the existing literature of the Holocaust on the grounds that it fails to take seriously the voice of the victims, seeking instead to explain the policy of extermination in casual terms. In this interpretive framework, the voice of the victims is simply redundant. The author is interested in bringing forward the wartime experiences of Jews and the texts written by them (diaries, letters, etc) as an area of concern to cultural history. If cultural history is about the production of meaning, then these texts are central in understanding these experiences through social psychology, ethnography and anthropological history and the study of language, speech and discourse. The author insists that the marginalisation of victims' voices is a serious deficit and proposes an understanding of Jewish experiences in relation to the fundamental transformations of human life brought about by the destruction of war and genocide. The politics of memory of the Nazis is the subject of Rupnow's essay, which rejects the view that the Nazis suppressed memory, arguing instead that Nazi politics of memory oscillated between "visibility and nonvisibility, between telling and silencing". They deliberately erased evidence of mass extermination in many cases so that the memory of these events disappeared, but they also organised various events and performances representing their crimes as heroic deeds, preserving photographs and films and staging the exhibition of the "Eternal Jew" to prepare the ground for the "final solution". Rupnow also tackles the sensitive issue of the meaning of the Holocaust as an event which is unrepresentable and incomprehensible, suggesting that this perspective comes near to exculpating the perpetrators. Understanding Nazi crimes is not simply about the past but also about our (precarious) present. Existing interpretations of the Holocaust have failed to consider the "green" nature of Nazi politics and especially the project of exterminating the Jews as an ecological event. In his fascinating essay, Neuman presents the making of Nazi extermination policy as analogous to an environmental project in which the Jews were "weeds" or "rats", whose eradication guaranteed the environment and Lebensraum for the "worthy". Neuman underscores the ecological metaphors the Nazis used to designate the "Jew" not simply as a racial "Other" but also as hazardous organism harmful for the environment. By describing Jews as rats, weeds and lice, the Nazis deprived them of their right to be human. New technologies related with the concentration camps - the barbed wire and Zyklon B were used extensively to incarcerate the Jews as hazardous organisms detrimental to the environment, exactly like lice or fleas, a pesticide for which Zyklon B was first developed.

The second part discusses issues of testimony and commemoration, with contributions by Samuel Moyn, Zoë Waxman and Doris Bergen. The testimonies of the victims have become the field of methodological conflicts. Diaries, letters and biographies are the kind of material that accommodates different perspectives and provokes different reactions. Moyn questions the salience of witnessing in the study of the Holocaust by historicising the concept of the 
witness and wondering about the cultural preconditions that made Jewish witnessing both familiar and intelligible. If the voice of the witness is not the natural response to violence, as Moyn seems to accept, then what accounts for the major role of these voices in the study of the Holocaust? The author suggests that next to the use of the witness in history and law, there is also a religious component in witnessing that should not be neglected. He proposes to understand the formation of Holocaust witnessing as the expression of the incomplete, secular improvisation of a Christian theme, the Jew as bearing witness to the truth of Christianity, in the political climate of the cold war which allowed the reconciliation of Christianity and Judaism in the face of atheism and communism. Under this light, Moyn sees the salience of the voice of the witness in the study of the Holocaust as the "blending of religious tropes and secular and ideological purposes", which somehow limits their scope to avoid domestication and foster disbelief. On the other hand, Waxman defends testimonies as meaningful documents which should not simply be mined for data but also as texts which can be read and understood in their own terms without erasing the identity of the victims. Historians should ask themselves why testimonies were written with the prospect of understanding this kind of material as an attempt to make sense of (precarious) lives. Therefore, the author suggests, historians have to move away both from the view that considers testimonies as sources of information and the view that testimonies are sacral mystical texts which defy interpretation. Bergen discusses the relation of history and commemoration by taking issue with four familiar slogans often used in the public discourse on the Holocaust and in many commemorative events. "All it takes for evil to triumph is for good men to do nothing", "The power of one", and the "Triumph of the human spirit" are three popular slogans which embody interpretations of the Holocaust based on individual agency or the lack of it. Bergen argues that historical study of the Holocaust reveals that individual agency was almost entirely erased by forces and dynamics - the military, bureaucratic organisation, education, antisemitism, the exigencies of war - which made individuals almost powerless and limited their agency almost completely. The slogan "Never again", on the other hand, reveals the paradox of holding the Holocaust as unique and, at the same time, using it as the template for other limit or genocidal events which abounded in the twentieth century. However, Bergen suggests, the study of the Holocaust was transformed by the study of other limit events in Rwanda, Cambodia and elsewhere. Thus, in this connection it lost its "unique" status, something which makes the Holocaust not less but more challenging.

The contributors to part three examine issues concerning the representation of the Holocaust. Saul Friedlander and Hayden White propose their own perspectives of Holocaust representation, and Wulf Kansteiner provides a stimulating reading of Friedlander using some of White's insight. Friedlander offers a new interpretive perspective combining research of German policies with the initiatives and reactions of all the authorities in occupied Europe. Jewish perceptions should not be excluded from an integral history of the Holocaust and, in addition, attention should be made for representing the events of the Holocaust simultaneously in order to enhance the magnitude and complexity of its history. Friedlander criticises historians who view the Holocaust from the perspective of some kind of instrumental rationality and downplay the central position of the Jewish issue in Nazi ideology and discourse. He suggests that an integrated narrative of the Holocaust must be in the form of a chronicle, without excluding general assump- 
tions about the context which made the extermination of European Jewry possible. It is not peculiar that Friedlander proposes the necessary dimensions of an integrated history of the Holocaust and a form of narration which should accommodate the vast diversity of the events that made up the Holocaust, cast in a succession of time units. White examines the modes of representing limit events and the Holocaust in particular by taking issue with the "is it true?" question associated with the foundation of historical truth. He suggests that the declarative mode favoured by most historians cannot do justice to the testimonies of victims in so far as the historian asks the "question is it true". This kind of testimony - White uses Primo Levi's Se questo e un uomo as his example - speaks in a different mode and describes the world of concentration camps, poetically telling us not what has happened, which actually preoccupies the historians, but what it felt like. White is clearly on familiar grounds by raising issues which problematise the concept of "testimony" and "historical source", extending them beyond conventional understandings. For all those familiar with White's critique of professional historiography, the praise of "artistic" representation of historical events does not sound strange. On the contrary, White believes that as professional historiography struggled to become scientific, it lost touch with literature and the philosophy of history and, as a consequence, displayed little regard for existential and ethical issues that cannot be verified with the rules of historical evidence alone. White's essay in this volume is another compelling piece in support of this thesis. Friedlander's book The Years of Extermination was enthusiastically received by historians, with most reviews praising the book as a monumental work in the study of the Holocaust. Kansteiner's reading of Friedlander's book does not limit itself to what was considered its major contribution and original- ity, namely the integration of victims' voices in the narrative of the Holocaust, but extends his analysis to include the narrative and rhetorical strategies of the book to which little attention was paid. Friedlander explains the Holocaust in terms of antisemitism but, Kansteiner suggests, his narrative does not follow standards of causality. On the contrary, he complicates the story with cases which point in different directions as far as the motives of victims, perpetrators and bystanders are concerned. He also confuses time and space, oscillating between different locations and chronologies. In this light, The Years of Extermination is a modernist œeuvre which challenges linear-narration ordering despite the fact that at first sight it seems to follow precisely this kind of ordering, an oeuvre that attempts to capture the chaotic and the futile element in the Holocaust, defies domestication and acknowledges, however implicitly, the limits of conventional historical representation.

In the final part of the book, contributors focus on the relation of the Holocaust with broader context(s) in order to put it into some kind of comparative perspective. One by one, Donald Bloxham, Federico Finkelstein and Dirk Moses question the "uniqueness" of the Holocaust and discuss it in relation to similar events. Bloxham and Moses thematise the Holocaust in relation to a broader context in which other genocidal events took place in the present or in the past. Bloxham argues that the emergence of the nation-state and the concomitant destruction of all continental empires in the nineteenth and early twentieth centuries provide the necessary context for us to understand that genocidal politics were an integral part in the rise of nationalism. The Holocaust, therefore, should be seen within this wider context of ethnic destruction, as part of the European experience, along with other wider structural forces such as industrialisation, ru- 
ral depression and urban migration. The Holocaust can only be explained within this broader movement of forces, which made possible the gestation of the "final solution" as one way of solving the Judenfrage along with that of the forced migration of the Jews from Europe. The radicalisation of Nazi policy, at the higher and lower levels, occurred only within context of the changing prospects of the war and in relation to the need to deal with the increasing number of Jews sent eastwards by various agencies. To the extent that the extermination of the Jews did not involve only German authorities but also authorities of other states in occupied Europe, the Holocaust becomes a ground for comparison within a broader framework. Moses puts forward a similar perspective of "de-provincialising" the Holocaust, though he is reaching further into the past. Following Raphael Lemkin, the Polish-Jewish jurist who coined genocide as a legal term in the public discourse of limit events, Moses suggests that genocides are both universal and diachronical. Although the legal content of genocide became available only after the second world war, there are many events in the past which can certainly be included in this category. Seen from this perspective, the Holocaust is only one example of a genocidal event; it is probably one of the most extreme forms, but it is certainly not unique. Finkelstein voices his objections to the study of the Holocaust as an event with little relation with fascism and proposes a transnational approach of fascism outside the strict framework of Nazism. If fascism is a broader phenomenon, then it has links with similar phenomena such as racism and empire and, to this extent, to the study of Holocaust as well.

The issues discussed in the book are interesting and insightful, and I hope that my short presentation of each one of the essays does justice to the major points they raised. The book is ordered in three parts, which overlap but also differ in perspective. In my view, there is one theme which needs further consideration because, to one degree or another, it is found in most essays. This is the "uniqueness" of the Holocaust thesis, which preoccupies most contributors albeit with different emphasis. The study of the Holocaust has taken various turns. Intentionalist and functionalist perspectives have deeply influenced this field, providing alternative explanations. The first emphasises the racial ideological convictions of Nazism and the expressed intentions of its leaders as the cause for the extermination of the Jews while the second points towards more pressing structural reasons which pushed Nazi policies to the extreme due to the exigencies of the war effort. According to this perspective, the changing fate of war in the east radicalised decision-making as far as Jews were concerned and sealed their fate. The sharp divisions of the past have now been surpassed as most historians acknowledge that ideological convictions and the radicalisation of bureaucratic mechanisms due to war exigencies can certainly be combined in understanding Nazi politics. However, despite the accumulation of new knowledge about the Third Reich, the question about the uniqueness of the Holocaust remains. It seems like the more we know about the Holocaust, the less probable historiographical consensus becomes. The proponents of the uniqueness of the Holocaust form a broad spectrum. Some consider the Holocaust as an event which lies outside history altogether, as something so extreme that it will forever transcend our mental capacities to grasp or even represent it. Others like Friedlander, in this volume and elsewhere, stress the fact that the Jews were exterminated only for being Jews and for no other reason, something which became tragically manifest in the last stages of the war when this kind of killing, although totally meaningless even to 
the perpetrators, was carried out systematically and incessantly. Most contributors to this volume argue against the uniqueness of the Holocaust. Stone, Bloxham, Moses and others suggest that the Holocaust is better explained if put in wider contexts, not only because the forces which made this event possible extended far outside the European continent but also because the sacralisation of the Holocaust makes the suffering of other groups appear less important. Is the experience of these groups so much different from those Jews who suffered in Birkenau, Treblinka or Chelmno? Is their memory less important than the memory of Bergen-Belsen or Auschwitz I? On the other hand, one might argue that every limit event is unique in its own terms and that stressing the differences between them is important. Industrialised death and racial prejudice were in the case of the Jews the marks of a "unique" modality of dying and suffering, which were quite different from the genocide in Rwanda or the Armenian genocide. For the dead victims, perhaps, the difference is minimal since all died in terrible ways, but for historians this should be important. Contextualising the Holocaust, or any other limit event for that matter, is useful, but one should be cautious lest he or she forgets that context(s) are simply interpretations of a commanding mode/ sort, useful for placing historical phenomena within a particular timeframe, sensitising historical perspectives and suggesting underlying relations, but they are not the rocks of reality which restrict interpretations of local events. On the other hand, the sacralisation of the Holocaust which is served by the uniqueness thesis, is in my mind, approaching ossification. The Holocaust is no less understandable or representable than any other limit event. The moral enormity of the Holocaust, the sheer size of the destruction of human lives involved, does not mean that this event defies understanding. The size of destruction does not di- minish the need to understand, which as Hannah Arendt put it, does not equal forgiveness. Neither does it mean that other limit events, in Africa, Asia or Europe, are less important.

However, to contend that the Holocaust is understandable and representable does not imply that this is so on the basis of the archive alone. The archive, as the sum of sources and histories compiled by specialists for the purpose of examining a particular phenomenon and establishing the factuality of particular events, is necessary as the condition of possibility of any historical statement. But the archive does not include everything; it excludes many traces, testimonies or events which do not comply with the acceptable rules of historical recognition. Of course, the archive is always in the process of renewing itself, of integrating new material and new traces of the past hitherto unnoticed, but there is always something the archive fails to register. If this is correct, then the idea of integrative history(ies), of an all-inclusive narrative, seems to be impossible if for no other reason because different material, especially material which until some point in time did not merit a place in the archive, upsets the rationalisation offered by the archive. I think that the voice of the Holocaust victims, perhaps of all victims of limit events, is a case in point. For conventional historical reason, these voices, despite their moral weight, may sound inaccurate, sentimental or simply impressionistic, entirely unable to point to the reasons of catastrophe. These voices echo the fear, anger or desperation of the victims but say nothing about the causes of the Holocaust because the victims were not responsible for what befell them and could not understand it. The voice of the victims gives testimony to the question "what was it like" instead of "what happened" and, for this reason, it belongs to a different registry than the official documents or similar material. The real 
question is whether an integrative narrative of the Holocaust, one including a formal historical narrative focusing on "what really happened", can be combined with a narrative, in whatever form, which accommodates the voice of the victims. Is it possible that, as Marc Nichanian suggests, ${ }^{1}$ the archive enables the negation of genocides because the genocidal will, which erases all traces of its murderous actions, is confident that historical adjudication based on the archive alone for the confirmation of documentary evidence will always leave enough room for non-decidability. If there are no documents, then there is no proof for the intentions and machinations of the genocidal will, even if the testimonies of survivors are available but unable to testify to that. If history demands proof and the archive does not hold this kind of evidence, then the genocide did not happen. I am not certain whether I can follow this line of argumentation, which is fostered by the denial of the Armenian genocide, though I admit that I find it forceful. As a critique of history, it raises the question of whether this discipline can integrate the voice of the victims, which is not always consistent or reasonable, or will it always be in the business of rationalising the past, thus leaving outside of the archive everything that resists rationalisation. But if history cannot integrate the voices of the victims of limit events, if the discipline of the archive cannot grasp the desperation of victimhood, then maybe a historically and philosophically informed art can.

\section{NOTE}

1 Marc Nichanian, The Historiographic Perversion, New York: Columbia UP, 2009.

\section{Odette Varon-Vassard}

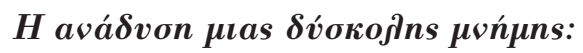

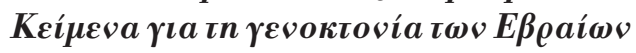

[The emergence of a difficult memory: Texts on the genocide of the Jews]

Athens: Estia, 2013 (2nd rev. ed.). 230 pp.

\section{Effi Gazi}

University of Peloponnese

This book is a compilation of 19 essays - two more than in the first edition - that the author produced in the course of approximately two decades in the form of scholarly articles, book presentations, seminar papers and public interventions. They reflect the process of scholarly research on Jewish history and Holocaust history in Greece as well as the author's critical reflections on these topics.

The book is structured around a number of broad themes, including the various histories of the Jewish communities in Greece, the history and memory of the genocide of the Greek Jews, genocide testimonies, and literary and filmic representations of the Holocaust. The author opts for the term "genocide" to refer to the mass destruction of European Jewry by the Nazis, noting the religious underpinnings of the term "holocaust" which are connected to notions of voluntary sacrifice. This is, of course, a succinct and convincing argument, although the term "holocaust" has been established in various contexts in recent decades and stands as a generic term for a formative event. In this sense, we should perhaps take into account its current uses as well as its detachment from earlier connotations.

The book focuses particularly on the ways and the various reasons the genocide of the 